\title{
Analysis of rabies diagnosis in dogs and cats in the state of São Paulo, Brazil
}

\author{
Juliana Galera Castilho ${ }^{1}$. Samira Maria Achkar ${ }^{1} \cdot$ Rafael de Novaes Oliveira $^{1}$ • Enio Mori ${ }^{1} \cdot$ Pedro Carnieli Jr $^{1}$. \\ Carla Isabel Macedo ${ }^{1}$
}

Received: 28 November 2017 / Accepted: 24 March 2018 / Published online: 8 May 2018

(c) Springer-Verlag GmbH Austria, part of Springer Nature 2018

\begin{abstract}
The genetic lineage of rabies virus (RABV) associated with dogs has not been found in the state of São Paulo since 1998, and all cases of rabies in domestic animals reported since then have involved the RABV lineage that circulates in bats. As there has been a change in the rabies transmission cycle in cats and dogs, we decided to analyze the tests used to diagnose rabies in these animals in the 15-year period from 2002 to 2016 in the state of São Paulo. During this period, 85,508 central nervous system (CNS) samples from dogs and cats were submitted to the Rabies Diagnosis Section at the Pasteur Institute of São Paulo for testing. All of the samples were tested by the fluorescent antibody test (FAT) and at least one of the following three tests: mouse inoculation test (MIT), rabies tissue culture infection test (RTCIT) and reverse transcription polymerase chain reaction (RT-PCR). Of all the samples tested, twenty were positive in at least one of these assays. Four other positive samples were identified at other institutions in the state of São Paulo. Of the twenty samples that tested positive at the Pasteur Institute of São Paulo, nine were tested by FAT, and the results were subsequently confirmed by other techniques; five gave inconclusive results, and therefore, other techniques had to be used as soon as possible in case the samples were positive; and six were negative by FAT and positive by one or more of the following tests: RTCIT, MIT and RT-PCR. Genetic typing of isolates from eighteen samples identified them as the lineage circulating in bats. In light of this finding, which indicates that genetic lineages associated with bats are circulating in domestic animals in the state of São Paulo, when the results of FAT carried out with samples from aggressive cats and dogs are inconclusive, complementary tests should be used. Decomposing samples and samples for which FAT was inconclusive should be tested using molecular techniques so that a definitive result can be obtained quickly and timely post-exposure prophylaxis can be administered to exposed individuals.
\end{abstract}

\section{Introduction}

Rabies is one of the most important zoonoses affecting the central nervous system (CNS) of mammals. It is caused by a viral agent, rabies virus (RABV), which belongs to the family Rhabdoviridae, genus Lyssavirus, species Rabies lyssavirus $[1,2]$.

There are two major epidemiological cycles of rabies: the urban cycle, in which dogs are responsible for most of the human rabies cases, and the sylvatic cycle, which may have different wild species as reservoirs, depending on the

Handling Editor: Marc H. V. Van Regenmortel.

Juliana Galera Castilho

juliana.castilho@uol.com.br

1 Pasteur Institute, Av. Paulista 393, São Paulo, SP CEP 01311-000, Brazil geographical area. In Latin America, the two cycles represent important economic and public-health problems [3]. Although the incidence of canine rabies in many countries has decreased following mass vaccination of dogs and cats, transmission by bats remains a problem [4].

In Brazil, rabies has exhibited a distinct epidemiological pattern in recent years, and the role of dogs as transmitters of the virus has become less important, while the sylvatic cycle has gained importance. This reduction in human rabies transmitted by dogs is due to the prophylactic program implemented by the Brazilian Ministry of Health to control rabies in domestic animals. In some regions of Brazil, the change in epidemiological profile is comparable to that found in developed countries, where rabies has become less common in domestic animals and more common among wild animals $[5,6]$.

Between 2002 and 2016, 1,705 and 174 cases of rabies in dogs and cats, respectively, were reported in Brazil. 
Of these, 1,071 cases in dogs and 106 cases in cats were reported in the first three years alone, and there was a major reduction in the last 12 years. Since 2005, there has been a significant decrease in the number of cases, due to better surveillance, vaccination of dogs and cats, and education of the population. In the same period (2002 to 2016), 125 cases of human rabies were reported. In 44 of these, rabies was transmitted by dogs; and in three, by cats. In the other cases the source of the infection was hematophagous bats, marmosets or herbivores [6].

Rabies is enzootic and epizootic in the state of São Paulo and primarily affects livestock and bats. However, cats and dogs have also been diagnosed with the disease in urban areas. The last case of canine rabies caused by antigenic variant 2 (AgV2) in the state was reported in 1998 [7]. Between 1998 and 2001, a total of 28 cases of rabies in dogs and cats were reported (23 and 5, respectively). Antigenic typing of samples from 22 of these using a panel of eight monoclonal antibodies provided by the CDC [8] showed that the variant in 21 of them was $\mathrm{AgV} 3$, the variant associated with hematophagous bats of the species Desmodus rotundus [7].

In the subsequent 15 years (2002 to 2016), 24 positive cases were reported in the state ( 8 in dogs and 16 in cats) [6]. Castilho et al. described 10 cases of rabies in dogs and cats between 2005 and 2014 ( 5 in dogs and 5 in cats), and in each case, genetic typing indicated that the disease had been transmitted by bats [9]. During the same period, 478 cases of rabies-positive bats were reported (Pasteur Institute data), showing the importance of the sylvatic cycle in the transmission of rabies to domestic animals in the state.

Between 1998 and 2016, there was an average of approximately three cases of rabies a year (52 cases diagnosed in 19 years), which indicates that bat-transmitted rabies in dogs and cats is enzootic in these animals in the state of São Paulo.

In view of the change in the rabies transmission cycle in cats and dogs, this study sought to analyze the rabies diagnosis of these animals in the 15-year period from 2002 to 2016 in the state of São Paulo.

\section{Materials and methods}

\section{Samples}

Between 2002 and 2016, 85,808 CNS samples from dogs and cats from different municipalities in the state of São Paulo were submitted to the Rabies Diagnosis Section at the Pasteur Institute of São Paulo for testing (Fig. 1).

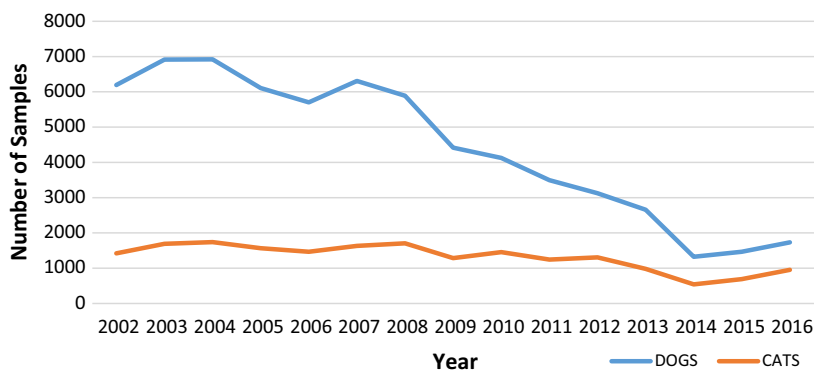

Fig. 1 Samples from dogs and cats from the state of São Paulo submitted to the Pasteur Institute of São Paulo for rabies diagnosis from 2002 to 2016

\section{Fluorescent antibody test (FAT)}

All samples were tested using a fluorescent antibody test (FAT) as described previously [10].

\section{Mouse inoculation test (MIT) and rabies tissue culture infection test (RTCIT)}

All samples that had not autolyzed when they were received were tested by MIT [11] and/or RTCIT as described previously [12].

\section{RT-PCR and DNA sequencing}

Total RNA was extracted from brain tissue from the suspected rabid animal using TRIzol ${ }^{\circledR}$ Reagent (Invitrogen) according to the manufacturer's instructions in the following cases: when the samples had autolyzed, when FAT was positive or inconclusive, or when the rabies virus had been isolated from the sample. RT-PCR was performed with the 504-sense primer (TATACTCGAATCATGATGAAT GGAGGTCGACT) and the 304-antisense primer (TTG ACGAAGATCTTGCTCAT) as described previously [13]. The amplified DNA fragment was then purified using a GFX $^{\mathrm{TM}}$ PCR DNA Kit (GE Healthcare), and sequencing was performed using a BigDye ${ }^{\circledR}$ Terminator v3.1 Cycle Sequencing Kit (Applied Biosystems) using the above sense and antisense primers according to the manufacturer's instructions. DNA sequences were determined using an ABI 3130 Genetic Analyzer (Applied Biosystems ${ }^{\mathrm{TM}}$ ).

The raw sequences were edited manually in Chromas (version 2.24, (c) 1998-2004 Technelysium Pty Ltd.), compared with sequences in GenBank using the app Blastn (available at https://blast.ncbi.nlm.nih.gov/Blast.cgi), and classified into different RABV lineages. 


\section{Results}

Of the 85,808 samples, 85,788 were negative by FAT and virus isolation (MIT and/or RTCIT) and 20 were positive by at least one of the techniques described in Materials and methods. Four other positive samples were tested for rabies at other institutions in the state of São Paulo.

The results for the 20 positive samples tested at the Pasteur Institute of São Paulo were analyzed here. Table 1 provides the following information about the samples: the year in which the sample was collected, the Pasteur Institute registration number, the species from which the sample was taken, the municipality in which the sample was collected, and the diagnostic techniques used (FAT, RTCIT, MIT and RT-PCR/genetic sequencing).
Of the 20 positive samples, nine tested positive by FAT, and the results were subsequently confirmed by other techniques; five had an inconclusive result by FAT, and other assays using different techniques had to be carried out as soon as possible if the samples were positive; and six were negative by FAT and positive by one or more of the following tests: RTCIT, MIT and RT-PCR. Four samples from CNS of cats from the municipalities of Mogi Mirim, Mairiporã, Guararapes and Araçatuba (no registration numbers available) were analyzed in other laboratories in the rabies diagnostic network, but no information was available about the assays used to test these samples (Table 1).

Of the nine samples that were positive by FAT, six (6901/10, 7146/11, 3313/14, 3251/15, 3405/16 and 3687/16) were positive in all the other assays (RTCIT, MIT and RTPCR), one (5243/02) was confirmed by MIT and was not tested by RTCIT or RT-PCR, one (11099/3) was confirmed

Table 1 CNS samples of Felis catus and Canis lupus familiaris diagnosed as positive for rabies by different techniques between 2002 and 2016

\begin{tabular}{|c|c|c|c|c|c|c|c|}
\hline Year & $\mathrm{R} \mathrm{N}^{\mathrm{a}}$ & Species & Municipality & FAT & RTCIT & MIT & RT-PCR/genetic lineage \\
\hline 2002 & $5243 / 02$ & Felis catus & Alto Alegre & $\mathrm{P}$ & ND & $\mathrm{P}$ & c \\
\hline 2002 & $\mathrm{~b}$ & Canis lupus familiaris & Mogi Mirim & & & & c \\
\hline 2003 & $11099 / 03$ & Felis catus & Cotia & $\mathrm{P}$ & ND & $\mathrm{N}$ & $\mathrm{P} /$ Desmodus rotundus \\
\hline 2004 & $\mathrm{~b}$ & Felis catus & Mairiporã & & & & $\mathrm{c}$ \\
\hline 2004 & $\mathrm{~b}$ & Felis catus & Guararapes & & & & $\mathrm{c}^{*}$ \\
\hline 2006 & $8406 / 06$ & Canis lupus familiaris & Guaraçaraí & $\mathrm{N}$ & ND & $\mathrm{P}$ & $\mathrm{P} /$ Desmodus rotundus \\
\hline 2010 & $6901 / 10$ & Felis catus & Jaguariúna & $\mathrm{P}$ & $\mathrm{P}$ & $\mathrm{P}$ & $\mathrm{P} /$ Desmodus rotundus \\
\hline 2010 & $\mathrm{~b}$ & Felis catus & Araçatuba & & & & $\mathrm{c}$ \\
\hline 2011 & $7146 / 11$ & Felis catus & São Paulo & $\mathrm{P}$ & $\mathrm{P}$ & $\mathrm{P}$ & $\mathrm{P} /$ Desmodus rotundus \\
\hline 2012 & $4153 / 12$ & Felis catus & Ribeirão Preto & I & $\mathrm{P}$ & $\mathrm{P}$ & $\mathrm{P} /$ Desmodus rotundus \\
\hline 2012 & $1881 / 12$ & Canis lupus familiaris & Ribeirão Preto & I & $\mathrm{N}$ & $\mathrm{P}$ & P/Desmodus rotundus \\
\hline $2012 *$ & $6527 / 12$ & Canis lupus familiaris & Rio Claro & $\mathrm{N}$ & $\mathrm{N}$ & $\mathrm{N}$ & $\mathrm{P} /$ Desmodus rotundus \\
\hline 2014 & $3312 / 14$ & Canis lupus familiaris & Ribeirão Preto & I & $\mathrm{P}$ & $\mathrm{N}$ & $\mathrm{P} /$ Desmodus rotundus \\
\hline 2014 & $3313 / 14$ & Canis lupus familiaris & Ribeirão Preto & $\mathrm{P}$ & $\mathrm{P}$ & $\mathrm{P}$ & $\mathrm{P} /$ Desmodus rotundus \\
\hline 2014 & $3262 / 14$ & Felis catus & Campinas & $\mathrm{N}$ & I & $\mathrm{P}$ & $\mathrm{P} /$ Nyctinomops sp \\
\hline $2015^{*}$ & $3752 / 15$ & Canis lupus familiaris & Campinas & $\mathrm{N}$ & ND & $\mathrm{N}$ & $\mathrm{P} /$ Desmodus rotundus \\
\hline 2015 & $1627 / 15$ & Felis catus & Ribeirão Preto & I & I & $\mathrm{N}$ & $\mathrm{P} /$ Nyctinomops sp \\
\hline 2015 & $3251 / 15$ & Felis catus & Ribeirão Preto & $\mathrm{P}$ & $\mathrm{P}$ & $\mathrm{P}$ & $\mathrm{P} /$ Desmodus rotundus \\
\hline $2015^{*}$ & $3812 / 15$ & Felis catus & Jaguariúna & $\mathrm{P}$ & ND & $\mathrm{N}$ & $\mathrm{N}$ \\
\hline 2016 & $3405 / 16$ & Canis lupus familiaris & Pindorama & $\mathrm{P}$ & $\mathrm{P}$ & $\mathrm{P}$ & $\mathrm{P} /$ Desmodus rotundus \\
\hline $2016^{*}$ & $2354 / 16$ & Felis catus & Pindamonhangaba & $\mathrm{N}$ & $\mathrm{N}$ & $\mathrm{N}$ & $\mathrm{P} /$ Nyctinomops laticaudatus \\
\hline 2016 & $3687 / 16$ & Felis catus & Ribeirão Preto & $\mathrm{P}$ & $\mathrm{P}$ & $\mathrm{P}$ & $\mathrm{P} /$ Desmodus rotundus \\
\hline 2016 & $4202 / 16$ & Felis catus & Campinas & $\mathrm{N}$ & I & $\mathrm{N}$ & $\mathrm{P} /$ Myotis sp \\
\hline $2016^{*}$ & $4485 / 16$ & Felis catus & Itapetininga & I & ND & $\mathrm{N}$ & $\mathrm{P} /$ Desmodus rotundus \\
\hline
\end{tabular}

FAT, fluorescent antibody test; RTCIT, rabies tissue culture infection test; MIT, mouse inoculation test; P, positive; N, negative; ND, not done; I, inconclusive

*samples with autolysis

${ }^{a}$ registration number at the Pasteur Institute

${ }^{\mathrm{b}}$ not done at Pasteur Institute

${ }^{c}$ antigenic (AgV3) and genetic (Desmodus rotundus) characterization done at Pasteur Institute

${ }^{* *}$ antigenic (AgV3) and genetic (Desmodus rotundus) characterization not done at Pasteur Institute 
by RT-PCR but was negative by MIT and was not tested by RTCIT, and one (3812/15) was not confirmed by MIT or RT-PCR and was not tested by RTCIT.

Of the five samples that had inconclusive results by FAT, one (4153/15) was positive by RTCIT, MIT and RTPCR; one (1881/12) was positive by MIT and RT-PCR; one (3312/14) was positive by RTCIT and RT-PCR, one $(1627 / 15)$ had an inconclusive result by RTCIT and was positive by RT-PCR, and one (4485/16), which was considered to have autolyzed, was positive only by RT-PCR.

Of samples that were negative by FAT, three were already decomposing when they were received $(6527 / 12,3752 / 15$ and 2354/16) and were only positive by RT-PCR, and the others were in a reasonable state of conservation. In two of these (one from a dog, 8406/06, and one from a cat, 3262/14) the virus was isolated at the end of the period when the inoculated mice were under clinical observation in the MIT (18 and 21 days, respectively). A sample from a cat (4202/16) was inconclusive by RTCIT but positive by RT-PCR.

Of the five samples in a state of decomposition (discussed in the previous paragraphs), one (3812/15) was positive only by FAT and was negative by MIT and RT-PCR. This sample was not tested by RTCIT.

Of the five samples in a state of decomposition (discussed in the previous paragraphs), one (3812/15) was positive only by FAT and was negative by MIT and RT-PCR. This sample was not tested by RTCIT.

DNA sequencing was performed to identify the genetic lineages in 18 of the 20 positive samples. In 14 of these, the genetic lineage was identified as the one circulating in D. rotundus (AgV3); and in four, as the lineage circulating in insectivorous bats. In three of the latter, the lineage was identified as the one circulating in Nyctinomops; and in one, as the lineage circulating in Myotis sp. One sample (5243/02) that was positive by FAT and MIT was not tested by RT-PCR, and sequencing was not performed. Consequently, it was not genetically typed (antigenic characterization, AgV3); another sample (3812/15), which had autolyzed and was positive by FAT, had a negative result by RT-PCR, probably because of the presence of an amplification inhibitor, and therefore could not be genetically typed.

These data show that there were 24 reported cases of rabies-positive $\operatorname{dogs}(n=8)$ and cats $(n=16)$ in the state of São Paulo between 2002 and 2016.

\section{Discussion}

Laboratory testing of CNS samples from suspected rabid dogs and cats should be accurate and timely, as prophylaxis and monitoring of other animals that may have come into contact with them depends on the results of these tests. If the results are positive or inconclusive, post-exposure anti-rabies prophylaxis must be administered immediately to the exposed individuals to prevent infection. Prophylaxis should be discontinued if the tests show that the animal was not excreting the virus in its saliva when the bite or scratch occurred.

FAT is advocated as the gold standard for diagnosing rabies and has a sensitivity of 95-99\% when fresh CNS samples are used [10]. Because the disease is nearly always fatal, RABV isolation in cell culture (RTCIT) or mice (MIT), which can detect the virus in samples with a low viral load, is also recommended to confirm a diagnosis by FAT [10].

The last case of dog rabies associated with the canine variant $(\mathrm{AgV} 2)$ in the state of São Paulo was reported in 1998 [7]. This long period without any reports of dog rabies caused by the canine variant can be attributed to the state's pioneering implementation of prophylaxis and control measures recommended by the Pan American Health Organization (PAHO) [14]. Between 1998 and 2016, there were 52 reported cases of rabies in dogs and cats in the state of São Paulo (31 and 21, respectively). In 46 of these, the virus was antigenically and genetically typed, and in 45 of these 46 , the virus was characterized as an antigenic variant or genetic lineage associated with bats $[6,7]$. These data show that there has been a change in the epidemiological profile of rabies over the last 20 years, and changes in the results of diagnosis and the behavior of rabid animals have consequently been observed. There is therefore a need for greater care when carrying out laboratory tests for rabies and when implementing surveillance measures at a municipal level.

In the 15-year period from 2002 to 2016, a total of 85,808 CNS samples from dogs and cats from the state of São Paulo were tested by FAT and RTCIT and/or MIT in the Rabies Diagnosis Section at the Pasteur Institute of São Paulo. Of all the samples tested, $20(0.023 \%)$ were positive in at least one of the tests, including RT-PCR (Table 1). Of these, only $6(0.007 \%)$ were negative by FAT and positive by at least one of the other methods (RTCIT, MIT, RT-PCR). Three of the six samples were from material that had started to decompose. These samples had atypical staining and odor and liquefied CNS structures that could not be identified.

In two of the samples that were in a reasonable state of conservation and were negative by FAT, the virus was isolated at the end of the period during which the inoculated mice in the MIT were under clinical observation, and in a third, the virus could not be isolated in mice and the RTCIT was inconclusive. These results suggest that the CNS samples of the animals had low viral loads.

Although the World Health Organization (WHO) recommends FAT as the gold standard for diagnosing rabies, external factors may affect the viral threshold for antigen detection, such as the time between the death of the animal and collection of the CNS, the time between collection of the CNS and dispatch to the laboratory, the quality and state 
of conservation of the sample, the quality of the fragments sent to the laboratory, the quality and source of the reagents used for the diagnostic tests, the condition of the test equipment, and the level of training of the personnel performing the tests [15-17]. For example, the sensitivity of FAT can be compromised in autolyzed samples $[15,16]$. Because FAT involves detecting the antigen directly in the suspected animal's nervous tissue and the viral antigen may be degraded, samples that have autolyzed may yield false negative results in the FAT assay.

When a sample submitted to the Pasteur Institute of São Paulo for testing is observed to have autolyzed, FAT and RTPCR are both performed to ensure a reliable diagnosis. The result is only issued when both tests have been completed. Studies have shown that when used with naturally infected, decomposing samples, molecular techniques such as RTPCR yield good results $[18,19]$.

As RABV does not spread uniformly throughout the brain, appropriate sampling of the nervous tissue is important for rabies diagnosis [20]. The virus is usually transmitted from the inoculation site to the CNS through peripheral nerves by centripetal retrograde axonal transport. Therefore, when euthanasia is performed in the early stages of the disease, progression and dissemination of RABV in nervous tissue may be limited and distribution in the CNS sporadic because of the low level of viral multiplication. In such situations, the structure of choice for rabies diagnosis should be the brainstem [10]. Furthermore, the length of clinical illness is directly related to the presence, size, abundance and development of Negri bodies [21], which may also explain the difficulty in detecting rabies by direct immunofluorescence.

The importance of FAT lies in the assumption that an animal with a negative result does not eliminate the virus in its saliva [22]. RABV is present in the saliva of an infected animal only after it has spread through the CNS and migrated centrifugally to the salivary glands. Hence, a negative result for rabies in brain tissue by FAT indicates that the disease was not transmitted through contact with saliva [23].

In this context, the isolated cases in our population sample that were negative by FAT and in which the virus was isolated later are insufficient to justify a change in the medical procedure used worldwide for rabies post-exposure prophylaxis after diagnosis by FAT.

Five of the 20 positive samples had inconclusive results by FAT and were immediately tested by RT-PCR to clarify the diagnosis. All were positive by RT-PCR; in three samples, the virus was isolated in the MIT and/or RTCIT; in one, the result of the RTCIT was inconclusive; and one sample that was considered to have autolyzed was positive only by RT-PCR. All of the samples that were positive for rabies by RT-PCR were confirmed positive by genetic sequencing. This shows that molecular techniques play a fundamental role in confirming a laboratory diagnosis and allow timely adoption of specific control measures such as post-exposure vaccination and anti-rabies serum administration, since the choice of vaccination scheme is based on the results of laboratory tests on brain tissue from the aggressor animal. According to Fooks et al., molecular tests can be used to complement conventional rabies diagnostic tests [24].

According to Tordo and Sacramento, classical RT-PCR assays have proven to be a sensitive and specific tool for routine diagnostic [25], particularly when decomposed samples are used [18, 26, 27]. However, obstacles to adaptation of this technique in the diagnosis of rabies include cost, complexity, local acceptance of their use, and the need for maintenance of the expertise [24, 28].

Interestingly, Shuangshoti et al. found that the distribution of RABV in the brains of dogs varied according to the type of clinical manifestation observed (furious or paralytic rabies). RABV was more abundant in the furious form, particularly in the initial stages of the disease [29]. Viral RNA, however, was distributed almost uniformly in all brain regions, even in the initial stages of the disease, regardless of the clinical subtype. The cases analyzed here are more suggestive of the paralytic form of the disease, which may be a reason for the extremely small amount of the virus in the brain and the consequent inconclusive FAT results. These results were clarified by RT-PCR or virus isolation, although in some cases, the virus was isolated only after some time and only in a few animals, confirming the low viral load. In these cases, RT-PCR was fundamental for a speedy diagnosis.

Fourteen of the 18 samples that were genetically typed in this study were characterized as the lineage circulating in $D$. rotundus, which is now known to consist very probably of two distinct yet phylogenetically very close genetic lineages [30-34] maintained in independent epidemiological cycles by $D$. rotundus and the fruit-eating bat Artibeus lituratus. However, the existence of these two lineages has yet to be confirmed [9].

Artibeus spp. currently represent a public-health problem because they are present in large numbers in urban areas. Between 2006 and 2016, the Pasteur Institute of São Paulo diagnosed 139 cases of rabies in A. lituratus in the state of São Paulo. Castilho et al. hypothesized that rabies infection in dogs and cats was associated with A. lituratus [9], as D. rotundus is found more frequently in rural areas and forests $[35,36]$.

Genetic typing of four samples from cats revealed lineages consistent with the rabies virus isolated from the insectivorous bats Nyctinomops sp. (in three samples) and Myotis sp. (in one sample). These are the first reports of these lineages in domestic animals in the state of São Paulo $[9,37]$. Threlfall et al. noted that various bat species, particularly insectivorous bat species, live in urban areas, where they 
take advantage of and have adapted to anthropogenic environmental changes [38].

The four positive samples analyzed in other laboratories (Table 1) were antigenically typed with a panel of monoclonal antibodies provided by the $\mathrm{CDC}$, Atlanta, and were characterized as variant $3(\mathrm{AgV} 3)$ (Ministry of Health/Brazil data), which is associated with $D$. rotundus. One (a sample from a cat from Guararapes) was also genetically typed and identified as the lineage circulating in D. rotundus [39].

The findings of the present study show that reports of infection of domestic carnivores by RABV lineages found in bats is increasingly common, potentially explaining anomalous behavior in cats and dogs. They also show that it is more difficult to detect the virus by the conventional techniques recommended for rabies diagnosis when the virus is transmitted by bats. Morikawa et al. reported similar behavior in a case in Curitiba, Brazil, in 2010, when a cat without any of the characteristic signs of rabies (the animal died following a seizure) tested negative by FAT and positive by MIT on the seventeenth day after inoculation. The sample was subsequently characterized with the panel of monoclonal antibodies as $\mathrm{AgV} 4$, the variant associated with the insectivorous bat Tadarida brasiliensis [40]. The same antigenic profile is also shared by one of the RABV lineages maintained in bats of the genus Myotis [41].

The importance of bats in the maintenance of the rabies cycle can be observed by the number of samples received at the Pasteur Institute from 2002 to 2016, most of which were non-hematophagous bat samples: 39,627 with a positive rate of $1.6 \%$ (629). In addition to the diagnosis of rabies in dogs, cats and non-hematophagous bats, the Pasteur Institute also contributes to the diagnosis in other mammalian species for surveillance and control of rabies in the State of São Paulo. In the period from 2002 to 2016, 1,175 samples of hematophagous bats, 2,331 herbivores and 1,025 wild samples were analyzed, and the positive rate was 40 (3.4\%), $988(42.4 \%)$ and $5(0,49 \%)$, respectively. These diagnostic results are essential for surveillance in order to take effective action to control this disease.

These findings show that bats play a crucial role in maintaining circulation of RABV in urban environments where there are domestic animals. During the present study, there was an increase in epidemiological surveillance of bat-related rabies. At the same time, there was a significant increase in the number of individuals with complaints involving bat attacks who were seen at health centers [42], as well as an increase in the number of specimens submitted for laboratory diagnosis. The number of cases diagnosed for any infectious disease is known to represent only a small fraction of the actual number of cases of the disease. Therefore, since the number of bat-transmitted rabies cases diagnosed in dogs and cats alone in 19 years averaged 2.4 cases a year, bat-transmitted rabies in these populations can be considered enzootic or even epizootic [43]. The significantly higher number of samples from dogs than from cats (Fig. 1) is due to the fact that, until 2008, the number of samples used as a surveillance indicator corresponded to $0.2 \%$ of the dog population in each municipality. This parameter was established in 1990 by Schneider, who used information from the rabies control program and records for the period 1980 to 1986 [44]. However, over the years, the number of municipalities in the state of São Paulo that no longer took part in the control program increased from $30.6 \%$ in 2003 to $60.5 \%$ in 2013 [45].

In addition, on April 17, 2008, the governor of the state of São Paulo sanctioned law no. 12,916/08, which made it illegal to destroy healthy animals and only allowed euthanasia for animals with incurable disabilities and diseases or infectious and contagious diseases that constitute a risk for public health. The number of samples from cats sent for diagnosis remained relatively stable throughout the study period.

The increase in the number of rabies cases in cats observed over the years may be because vaccination campaigns were targeted at dogs and because of the difficulty involved in bringing cats to vaccination centers. Another possible explanation is related to the ethology of these animals, as they prey on bats, particularly insectivorous and frugivorous ones, that have lost their natural habitats and consequently cohabit with domestic cats in urban areas. In addition, according to Woods et al., there is a greater probability of cats coming into contact with bats and becoming infected because of their behavior and nocturnal habits [46].

It should be stressed that, of the 24 samples from the state of São Paulo that tested positive, 10 came from the municipalities of Ribeirão Preto and Campinas, which submit many samples for rabies testing and have a successful surveillance program, as part of which they send samples from animals that have neurological impairment, have exhibited aggressive behavior or have been involved in incidents, such as being run over by a vehicle, potentially indicating behavioral alterations.

In view of our finding that genetic lineages associated with bats are circulating in domestic animals, tests to complement FAT are essential when testing CNS samples from aggressive cats and dogs. Decomposing samples and samples with inconclusive results in FAT should be tested using molecular techniques so that a definitive result can be obtained quickly and timely post-exposure prophylaxis can be administered to exposed individuals.

\section{Compliance with ethical standards}

Funding This study was funded by Instituto Pasteur.

Conflict of interest The authors declare that they have no conflict of interest. 
Ethical approval All applicable international, national, and/or institutional guidelines for the care and use of animals were followed.

This study is a retrospective analysis of the diagnosis of rabies in which viral isolation in mice is one of the techniques recommended by the World Health Organization. The Pasteur Institute is the reference center for the diagnosis of rabies in Brazil, and all samples that are referred for diagnosis are subjected to these techniques that were analyzed in the study. Therefore, both the animal samples received and the laboratory animals used are part of the laboratory diagnosis routine for rabies. Thus, since this is not a study linked to a research project but an analysis of the diagnostic tests, there is no opinion of the ethics committee of the institution. The laboratory animals used routinely for the diagnosis of rabies are maintained according to federal legislation.

This study did not include human samples, so there was no need for an ethics committee opinion.

\section{References}

1. King AMK, Adans MJ, Carstens EB, Lefkowitz EJ (2012) Genus Lyssavirus. In: King AMQ, Adams MJ, Carstens EB, Lefkowitz EJ (eds) International Committee on Taxonomy of Viruses, 9th edn. Elsevier Inc., San Diego, pp 696-699

2. Fisher CR, Streicker DG, Schnell MJ (2018) The spread and evolution of rabies virus: conquering new frontiers. Nat Rev Microbiol. https://doi.org/10.1038/nrmicro.2018.11

3. Acha PN, Szyfres B (2003) Zoonoses y enfermeddes transmisibles comunes al hombre y a los animales, vol 2, 3rd edn. Organization Panamericana de la Salud, Washington

4. Schneider MC, Romijn PC, Uieda W et al (2009) Rabies transmitted by vampire bats to humans: an emerging zoonotic disease in Latin America? Rev Panam Salud Publica 25:260-269

5. Rocha SM, de Oliveira SV, Heinemann MB, Gonçalves VSP (2017) Epidemiological profile of wild rabies in Brazil (2002-2012). Transbound Emerg Dis 64:624-633. https://doi. org/10.1111/tbed.12428

6. Ministério da Saúde—Brasil (2017) Situação epidemiológicadados. http://portalsaude.saude.gov.br/index.php/o-ministerio/ principal/leia-mais-o-ministerio/752-secretaria-svs/vigilancia -de-a-a-z/raiva/11431-situacao-epidemiologica-dados. Accessed 1 Sep 2017

7. Kotait I, Favoretto SR, Carrieri ML, Takaoka N (2001) Raiva humana causada pela variante 3-Desmodus rotundus-no estado de São Paulo. In: Institute P (ed) Seminário Internacional: Morcegos Como Transmissores da Raiva, São Paulo, pp 70-71

8. Diaz AM, Papo S, Rodriguez A, Smith JS (1994) Antigenic analysis of rabies-virus isolates from Latin America and the Caribbean. Zentralblatt für Veterinärmedizin R B J Vet Med 41:153-160

9. Castilho JG, de Souza DN, Oliveira RN et al (2017) The epidemiological importance of bats in the transmission of rabies to dogs and cats in the state of São Paulo, Brazil, between 2005 and 2014. Zoonoses Public Health 64:423-430. https://doi.org/10.1111/ zph. 12320

10. Dean DJ, Abelseth MK, Atanasiu P (1996) The fluorescent antibody test. In: Meslin FX, Kaplan MM, Koprowski H (eds) Laboratory techniques in rabies, 4th edn. World Health Organization, Geneva, pp 88-93

11. Koprowski H (1996) The mouse inoculation test. In: Meslin FX, Kaplan MM, Koprowski H (eds) Laboratory techniques in rabies, 4th edn. World Health Organization, Geneva, pp 80-86

12. Castilho JG, Iamamoto K, Yoshitaka J et al (2007) Padronização e aplicação da técnica de isolamento do vírus da raiva em células de neuroblastoma de camundongo (N2A). Bol Epidemiológico Paul (BEPA) 4:12-18
13. Orciari LA, Niezgoda M, Hanlon CA et al (2001) Rapid clearance of SAG-2 rabies virus from dogs after oral vaccination. Vaccine 19:4511-4518

14. Takaoka N (2000) Alteração no perfil epidemiológico da raiva no Estado de São Paulo. In: Pasteur I (ed) Seminário Internacional de Raiva, São Paulo, pp 23-24

15. Albas A, Ferrari CI, da Silva LH et al (1999) Influence of canine brain decomposition on laboratory diagnosis of rabies. Rev Soc Bras Med Trop 32:19-22

16. McElhinney LM, Marston DA, Brookes SM, Fooks AR (2014) Effects of carcase decomposition on rabies virus infectivity and detection. J Virol Methods 207:110-113. https://doi.org/10.1016/j. jviromet.2014.06.024

17. Trimarchi CV, Davis Nadin SA (2007) Diagnostic Evaluation. In: Jackson AC, Wunner W (eds) Rabies, 2nd edn. Academic Press, San Diego, pp 411-469

18. David D, Yakobson B, Rotenberg D et al (2002) Rabies virus detection by RT-PCR in decomposed naturally infected brains. Vet Microbiol 87:111-118

19. Oliveira R, Takaoka N, Brandao P et al (2006) Postmortem confirmation of human rabies source [7]. Emerg Infect Dis 12:867-869

20. Bingham J, van der Merwe M (2002) Distribution of rabies antigen in infected brain material: determining the reliability of different regions of the brain for the rabies fluorescent antibody test. J Virol Methods 101:85-94

21. Tierkel E, Atanasiu P (1996) Rapid microscopic examination for Negri bodies and preparation of specimens for biological test. In: Meslin FX, Kaplan MM, Koprowski H (eds) Laboratory techniques in rabies, 4th edn. World Health Organization, Geneva, pp $55-65$

22. Charlton KM, Casey GA, Campbell JB (1983) Experimental rabies in skunks: mechanisms of infection of the salivary glands. Can J Comp Med Rev Can Med Comp 47:363-369

23. CDC - Center for Disease Control and Prevention (2006) Protocol for postmortem diagnosis of rabies in animals by direct fluorescent antibody testing: a minimum standard for rabies diagnosis in the United States. https://www.cdc.gov/rabies/pdf/RabiesDFASPv2. pdf. Accessed 22 Aug 2017

24. Fooks AR, Johnson N, Freuling CM et al (2009) Emerging technologies for the detection of rabies virus: challenges and hopes in the 21st century. PLoS Negl Trop Dis 3:e530. https://doi. org/10.1371/journal.pntd.0000530

25. Tordo N, Sacramento D, Bourhy H (1996) The polymerase chain reaction (PCR) technique for diagnosis, typing and epidemiological studies. In: Meslin FX, Kaplan MM, Koprowski H (eds) Laboratory techniques in rabies, 4th edn. World Health Organization, Geneva, pp 157-170

26. Araujo DB, Langoni H, Almeida MF et al (2008) Heminested reverse Transcriptase polymerase chain reaction (hnRT-PCR) as a tool for rabies virus detection in stores and decomposed samples. BMC Res Notes 1:17

27. Whitby JE, Johnstone P, Sillero-Zubiri C (1997) Rabies virus in the decomposed brain of an Ethiopian wolf detected by nested reverse transcription-polymerase chain reaction. J Wildl Dis 33:912-915

28. Rupprecht CE, Hanlon CA, Hemachudha T (2002) Rabies reexamined. Lancet Infect Dis 2:327-343

29. Shuangshoti S, Thepa N, Phukpattaranont P et al (2013) Reduced viral burden in paralytic compared to furious canine rabies is associated with prominent inflammation at the brainstem level. BMC Vet Res 9:31. https://doi.org/10.1186/1746-6148-9-31

30. Brandão PE, Carnieli Junior P, Castilho JG, et al (2004) Rabies virus versus frugivorous and vampire bats: evolutive and public health insights. In: Abstracts book of the XV International Conference Rabies in the Americas (XV RITA). organizer committee, Santo Domingo, pp 41-42 
31. Albas A, de Souza EAN, Lourenço RA et al (2009) Antigen profile of rabies virus isolated from different species of nonhematophagous bats in the region of Presidente Prudente, State of São Paulo. Rev Soc Bras Med Trop 42:15-17

32. Fahl WO, Carnieli P, Castilho JG et al (2012) Desmodus rotundus and Artibeus spp. bats might present distinct rabies virus lineages. Braz J Infect Dis 16:545-551. https://doi.org/10.1016/j. bjid.2012.07.002

33. Kobayashi Y, Sato G, Shoji Y et al (2005) Molecular epidemiological analysis of bat rabies viruses in Brazil. J Vet Med Sci 67:647-652

34. Shoji Y, Kobayashi Y, Sato G et al (2004) Genetic characterization of rabies viruses isolated from frugivorous bat (Artibeus spp.) in Brazil. J Vet Med Sci 66:1271-1273

35. Gomes MN (2008) Padrões espaciais da raiva bovina e seus determinantes no Estado de São Paulo entre 1992 e 2003. Instituto Nacional de Pesquisas Espaciais (INPE) São José do Campos

36. Sazima I (1978) Aspectos Do Comportamento Alimentar Do Morcegos Hematófago, Desmodus Rotundus. Bol Zool Univ São Paulo 3:97-120

37. Lucca T, Rodrigues RCA, Nitsche A, Von Zuben AP (2017) Ações de Vigilância e controle da raiva frente a caso positivo em felino no município de Campinas, São Paulo, Brasil. Bol Epidemiológico Paul 14:33-41

38. Threlfall CG, Law B, Banks PB (2012) Influence of landscape structure and human modifications on insect biomass and bat foraging activity in an urban landscape. PLoS One 7:e38800. https ://doi.org/10.1371/journal.pone.0038800
39. Queiroz LH, Favoretto SR, Cunha EMS et al (2012) Rabies in southeast Brazil: a change in the epidemiological pattern. Arch Virol 157:93-105. https://doi.org/10.1007/s00705-011-1146-1

40. Morikawa VM, Ribeiro J, Biondo AW et al (2012) Cat infected by a variant of bat rabies virus in a 29-year disease-free urban area of southern Brazil. Rev Soc Bras Med Trop 45:255-256

41. Albas A, de Campos AC, Araujo DB et al (2011) Molecular characterization of rabies virus isolated from non-haematophagous bats in Brazil. Rev Soc Bras Med Trop 44:678-683

42. Ministério da Saúde-Brasil (2012) Nota Técnica n. 19-CGDT/ DEVEP/SVS/MS. Diretrizes da vigilância em saúde para atuação diante de casos de raiva em morcegos em áreas urbanas

43. Pereira MG (1995) Doenças infecciosas. In: Koogan Guanabara (ed) Epidemiologia: teoria e prática, 1st. Guanabara Koogan S.A, Rio de Janeirol, pp 419-448

44. Schneider MC (1990) Estudo de avaliação sobre área de risco para a raiva no Brasil. Escola Nacional de Saúde Pública da Fundação Oswaldo Cruz

45. Martins CM (2015) Avaliação e proposta de reestruturação do sistema de vigilância da raiva humana, canina e felina no Estado de São Paulo. Faculdade de Medicina Veterinaria da Universidade de São Paulo

46. Woods M, Mcdonald RA, Harris S (2003) Predation of wildlife by domestic cats Felis catus in Great Britain. Mamm Rev 33:174188. https://doi.org/10.1046/j.1365-2907.2003.00017.x 